\title{
Evaluation of chemopreventive and chemotherapeutic effect of Artemisia vulgaris extract against diethylnitrosamine induced hepatocellular carcinogenesis in Balb $\mathrm{C}$ mice
}

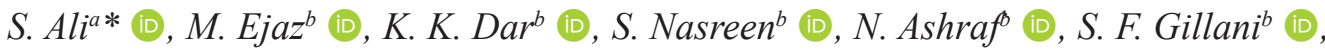 \\ N. Shafi (D), S. Safeer ${ }^{b}$ (D), M. A. Khan ${ }^{b}$ (D), S. Andleeb ${ }^{b}$, N. Akhtar ${ }^{\text {(D) }}$ and T. A. Mughal ${ }^{a}$

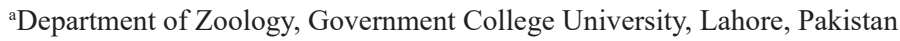 \\ ${ }^{b}$ Microbial Biotechnology and Medical Toxicology Laboratory, Department of Zoology, University of Azad Jammu and \\ Kashmir, Muzaffarabad, 13100, Pakistan \\ *e-mail: shaukatali134@yahoo.com
}

Received: September 30, 2017 - Accepted: February 26, 2019 - Distributed: August 31, 2020

(With 3 figures)

\begin{abstract}
The main objective of current study was to investigate the chemopreventive and chemotherapeutic activity of Artemisia vulgaris extract on diethylnitrosoamine induced hepatocarcinogenesis in Balb C mice. Diethylnitrosoamine (DEN: 0.9\%) was prepared to induce hepatocarcinoma in Balb C mice. The extract Artemisia vulgaris (AV) was prepared by maceration technique. Mice were classified into four groups as follows: Group 1 a control group $(\mathrm{N}=7)$ received saline solution $(3.5 \mu \mathrm{l} / \mathrm{mg})$, group $2(\mathrm{~N}=14)$ received diethylnitrosoamine $(3.5 \mu \mathrm{l} / \mathrm{mg})$ intraperitoneally once in a week for eight consecutive weeks, group $3(\mathrm{~N}=7)$ received only plant extract (AV: $150 \mathrm{mg} / \mathrm{kg}$ (Body weight) once in a week, while group $4(\mathrm{~N}=7)$ was given in combination of diethylnitrosoamine $(3.5 \mu \mathrm{l} / \mathrm{mg})$ and plant extract (AV: $150 \mathrm{mg} / \mathrm{kg}$ (body weight). After eight weeks of DEN administration, mice of group 2 were divided into two subgroups containing seven mice each; subgroup 1 was sacrificed while subgroup 2 was treated with plant extract only ( $150 \mathrm{mg} / \mathrm{kg}$ (body weight)) once in a week for eight consecutive weeks. The DEN injected mice significant decline in levels of albumin with concomitant significant elevations such as aspartate aminotransferase, alanine aminotransferase, lactate dehydrogenase, alpha feto protein, gamma glutamyl transferase, 5 nucleotidase, glucose-6-phosphate dehydrogenase and bilirubin. The administration of $A$. vulgaris significantly decreased the DEN induced hepatotoxicity. Present study revealed the potential anti-cancerous nature of Artemisia vulgaris, both in case of chemopreventive and post-treatment of $A$. vulgaris. Further studies are needed to explore the mechanism of prevention and therapy.
\end{abstract}

Keywords: Artemisia vulgaris, hepatocellular carcinogenesis, diethylnitrosoamine, alpha feto protein, Balb C mice.

\section{Avaliação dos efeitos quimiopreventivo e quimioterápico do extrato de Artemisia vulgaris contra carcinogênese hepatocelular induzida por dietilnitrosamina em camundongos Balb $\mathrm{C}$}

\section{Resumo}

O objetivo principal do presente estudo foi investigar as atividades quimiopreventiva e quimioterápica do extrato de Artemisia vulgaris em hepatocarcinogênese induzida por dietilnitrosoamina (DEN) em camundongos Balb C. Dietilnitrosoamina (DEN: 0,9\%) foi preparada para induzir hepatocarcinoma em camundongos da linhagem Balb C. $\mathrm{O}$ extrato de $A$. vulgaris (AV) foi preparado pela técnica de maceração. Os camundongos foram classificados em quatro grupos conforme os seguintes: grupo 1 , grupo controle $(\mathrm{N}=7)$ recebeu solução salina $(3,5 \mu 1 / \mathrm{mg})$; grupo $2(\mathrm{~N}=14)$ recebeu dietilnitrosoamina $(3,5 \mu \mathrm{l} / \mathrm{mg})$ por via intraperitoneal uma vez por semana durante oito semanas consecutivas; grupo $3(\mathrm{~N}=7)$ recebeu apenas o extrato vegetal (AV: $150 \mathrm{mg} / \mathrm{kg}$ (peso corporal) uma vez por semana; enquanto no grupo $4(\mathrm{~N}=7)$ foi administrado uma combinação de dietilnitrosoamina $(3,5 \mu 1 / \mathrm{mg})$ com extrato vegetal $(\mathrm{AV}: 150 \mathrm{mg} / \mathrm{kg}$ (peso corporal). Após oito semanas de administração de DEN, os camundongos do grupo 2 foram divididos em dois subgrupos, contendo sete camundongos cada um; no subgrupo 1, os animais foram sacrificados, enquanto no subgrupo 2 , os animais foram tratados apenas com extrato vegetal $(150 \mathrm{mg} / \mathrm{kg}$ (peso corporal)) uma vez por semana durante oito semanas consecutivas. Os camundongos nos quais foram injetados DEN apresentaram declínio significativo nos níveis de albumina, mas elevações significativas concomitantes de: aspartato aminotransferase, alanina aminotransferase, lactato desidrogenase, alfa-fetoproteína, gama-glutamiltransferase, 5' nucleotidase, glicose-6-fosfato desidrogenase e bilirrubina. A administração de $A$. vulgaris diminuiu significativamente a hepatotoxicidade induzida pelo DEN. O presente estudo apresentou a potencialidade anticancerosa da A. vulgaris, tanto nos casos de quimioprevenção quanto no pós-tratamento da $A$. vulgaris. Mais estudos são necessários para explorar o mecanismo de prevenção e a terapia.

Palavras-chave: Artemisia vulgaris, carcinogênese hepatocelular, dietilnitrosoamina, alfafetoproteína, camundongos Balb C. 


\section{Introduction}

Liver cancer or Hepatocellular carcinoma (HCC) is the sixth most normal malignancy and the third driving cause of cancerous deaths in the world (Ferlay et al., 2010). The load of malignancy is expanding in developing nations because of population increase and growth as well as, increasingly, an adaptation of cancerous related life style choices like reduced physical activity, smoking and western diets. An expected 748300 new HCC cases and 695900 cancerous deaths happened throughout the world. In Europe 60, 200 cases were diagnosed in 2008 (Jemal et al., 2011). Hepatitis viral diseases, alcohol, toxic industrial chemicals, aflatoxins, food additives, air and water contaminants are the real hazard elements of liver tumor (Farazi and DePinho, 2006). Human liver is the site in the body that utilizes ingested material. It has pore to cancer-causing affront. In addition, because of the high resilience of liver, $\mathrm{HCC}$ is sometimes distinguished at the early stage and once recognized, treatment confronts a poor anticipation much of the time (Singh et al., 2009).

Diethylnitrosoamine (DEN) is an intense hepatocarcinogenic nitrosamine introduced in tobacco smoke, water, cheddar, cured and singed suppers, word related settings, beauty care products, rural chemicals and pharmaceutical operators (Sivaramakrishnan et al., 2008). Diethylnitrosoamine is broadly acknowledged for inducing preneoplastic sores and hepatic tumors in rats and it is started by annoyances of atomic compounds required in DNA repair or replication (Khan et al., 2011). Examination have given proof that DEN causes a variety of cancers in all animal species and such compounds are perilous to human wellbeing (Ramakrishnan et al., 2006). Diethylnitrosoamine prompted injuries and also tumors in rodents demonstrate marked biochemical, histological and molecular similarities to the progress of HCC in people (Mcintyre and Rosalki, 1992; Feo et al., 2000).

In recent studies, identification of biologically active compounds from the therapeutic plants have been seen to hinder the carcinogenesis in various animal models of tumorigenesis, including particular organ sites such as the esophagus, oral cavity, skin, lungs, stomach, liver, pancreas, small intestine, colon and prostate has gained considerable consideration (Aggarwal and Shishodia, 2006). Naturally occurring compounds in plant are gaining increased consideration for the inhibition of tumour progression in the diverse stages of neoplastic diseases (Ravindranath et al., 2009). The plants are thought to be laxative, diuretic, anthelmintic, diaphoretic and utilized for the purifying blood and in the impediment of liver (Hussain et al., 2012). Artemisinins belong to family of sesquiterpene trioxane lactone that are used against malaria, derived from the sweet woodworm Artemisia annua, it is a restorative herb which has for quite some time been utilized as a part of Chinese medication to treat in various fevers. This essential anti-malarial derivative was obtained from Artemisinin, this compound is extracted in Chinese drug discovery from screen of herbal extract used against Plasmodium species in 1970s (Li, 2012). Among the Artemisinins, Artesunate is the most studied analogue because in addition, a hemi-succinate group which is considerably water-soluble and are highly orally bioavailable, bringing about more favorable pharmacological activities (Newton et al., 2000). Artemisia vulgaris L. (Mugwort) belongs to Asteraceae family, perennial herb in nature and distributed in hilly areas of India. In traditional medicine, this plant is being widely used for the treatment of diabetes and the extracts of the whole plant is used for epilepsy and in combination for psychoneurosis, depression, irritability, insomnia and anxiety stress. This is a potent medicinal plant as being widely used against diabetes, while the whole plant extracts are used against epilepsy, psychoneurosis depression, insomnia, irritability and anxiety stress (Walter and Memory, 2003). A. vulgaris played a medicinal role in treatment of uterine cancer (Shaik and Hussain, 2004), leaves past against skin diseases (Kapoor, 2000) and it acts as a vermifuge against intestinal parasites (George and Roger, 2000). The biologically active components are vulgarin, coumarins, sesquiterpene lactones, volatile oils (90\% effective against yellow fever) and inulin

(Reviewed in Bora and Sharma, 2011).

\section{Materials and Methods}

\subsection{Ethical statement}

All animal trial techniques were directed as per local and worldwide controls. The nearby direction is the Wet op de dierproeven (Article 9) of Dutch Law (international) and a similar law regulated by the Bureau of Animal Experiment Licensing, local University.

\subsection{Chemicals used}

Diehtylnitrosoamine (Sigma-Aldrich Chemical Co, St Louis, Mo, USA) and normal saline ( $\mathrm{NaCl} 0.9 \%$ w/v) were used.

\subsection{Animals}

Male Balb C mice (35-40 g) were acquired from the animal's house in National Institute of Health (NIH) Islamabad, Pakistan. The mice were kept in animal house having temperature $20-23{ }^{\circ} \mathrm{C}$ with $12: 12 \mathrm{~h}$ light/dark cycle in polypropylene confines. The mice were encouraged with standard nourish and water was given ad libitum.

\subsection{Preparation of diethylnitrosoamine}

One percent diethylnitrosoamine was prepared by using $99 \mathrm{ml}$ of normal saline $\mathrm{NaCl}(0.9$ percent $)$ solution to which was added $1 \mathrm{ml}$ of concentrated diethylnitrosoamine (DEN) solution $(0.01 \mu \mathrm{g} / \mu \mathrm{l})$.

\subsection{DEN induced hepatocellularcarcinoma}

Male balb C mice (35-40 g) were classified into four groups. Group 1 a control group $(\mathrm{N}=7)$ had received saline solution $(3.5 \mu \mathrm{l} / \mathrm{mg})$, group $2(\mathrm{~N}=14)$ received diethylnitrosoamine $(3.5 \mu \mathrm{l} / \mathrm{mg})$ intraperitoneally once in a week for eight consecutive weeks, group $3(\mathrm{~N}=7)$ was given combination of diethylnitrosoamine $(3.5 \mu \mathrm{l} / \mathrm{mg})$ and 
plant extract $(150 \mathrm{mg} / \mathrm{kg})$, while, group $4(\mathrm{~N}=7)$ received plant extract $(150 \mathrm{mg} / \mathrm{kg})$ once in a week.

\subsection{Plant material}

Leaves of Artemisia vulgaris were collected from Muzaffarabad, Azad Kashmir, Pakistan and washed with running tap water; air dried under shade, coarsely powdered and kept in airtight container for further use.

\subsection{Extract preparation}

Extract was prepared through maceration extraction method (Hafeez et al., 2017) Air dried powder was soaked in methanol for 20 days to increase the polarity at room temperature $\left(25^{\circ} \mathrm{C}-30^{\circ} \mathrm{C}\right)$. The crude extract was filtered through Whatmann filter paper I (Sigma Aldrich), evaporated under reduced pressure using rotary evaporator (Temp, $37^{\circ} \mathrm{C}$ and at speed of $100 \mathrm{rpm}$ ) to get the required concentration. The extract was then dissolved in water and methanol in proportion of 23:1 respectively for anti-cancer screening.

\subsection{In vivo pharmacological interventions against hepatocellular carcinoma}

After eight weeks of DEN induction group 2 mice were divided into two subgroups containing seven mice each, subgroup 1 was sacrificed while subgroup 2 was treated with plant extract $(150 \mathrm{mg} / \mathrm{kg})$ once in a week for eight consecutive weeks. According to the acute toxic classic method was presented by Hussain et al. (2012). For each step, three male Balb C mice were used in this study. The mice were kept fasting with water overnight and extract was administered intraperitoneally at a single dose of $150 \mathrm{mg} / \mathrm{kg}$. Mice were regularly observed for $4 \mathrm{~h}$ after initial administration and then once in a day for consecutive two weeks. If the mortality occurred in two of the three mice than the dose was toxic if not then this dose was used as standard. Mice survived at dose of $150 \mathrm{mg} / \mathrm{kg}$ and this dose was used as a standard in the whole experiment.

The concentration of higher dose than $150 \mathrm{mg} / \mathrm{kg}$ causes the acute and abrupt alteration within the metabolic and morphological activities of mice evanescently, which leads toward the death of experimental model within no time. The dose management is anfractuous step of our experiment because we experimentally observe the death of number of mice by higher dose than $150 \mathrm{mg} / \mathrm{kg}$.

\section{Biochemical Analysis}

After the final treatment, the mice were fastened overnight, and all of the rats were anesthetized with chloroform presented on a cotton ball and euthanized by cervical decapitation. Ethylene diamine tetra acetic acid (EDTA) tubes (size $13 * 75$, containing $\sim 1.8 \mathrm{mg}$ K2EDTA per $\mathrm{ml}$ blood) were used for collection of blood samples. Blood samples were centrifuged for a minimum of 10 minutes at 1000-2000 RCF (Relative Centrifugal Force). Centrifuged plasma was utilized for different biochemical assessment. The livers were extracted instantly from the mice, washed with ice-chilled physiological saline and refrigerated until examination.
The activities of biochemical parameters like aspartate transaminase (ASAT) and alanine transaminase (ALAT) were assessed by the method of (Reitman and Frankel, 1957) while Gamma glutamyl transferase (Y-GT) was assessed by methods of (King, 1965; Szasz, 1976). Total bilirubin level (TBL) was assessed by modified dimethyl sulfoxide (DMSO) method (Dangerfield and Finlayson, 1953) on the basis of sulfanilic acid reaction with sodium nitrite to produce deoxidized sulfanilic acid. Activity of lactate dehydrogenase (LDH) was assessed by the method described by (King, 1965). While total albumin level was measured by using procedure demonstrated by Savory et al. (1976). Activity of 5 nucleotidase (5NT) was measured by the process explained by (Rieder and Otero, 1969). G6DPH was assessed by the method explained by (Minucci et al., 2009). Quantitative measurement of cancer marker alpha fetoprotein (AFP) antigen (CEA) was based on solid phase enzyme linked immunosorbent assay using the UBI MAGIWELL (USA) enzyme immunoassay kit (Sell and Beckar, 1978; Sell et al., 1983; Macnab et al., 1978). Activity of G6PDH was assessed by the method explained by (Tepperman and Tepperman, 1962).

\section{Statistical Analysis}

GraphPad Prism for Windows (version 5.03) was used for Statistical analyses and also used for plotting graphs with error bars of standard errors of the means (SEM). To analyse the impact of different treatments on levels of biomarkers in mice, one-way analysis of variance and a Dunnett's multiple comparison test with probability level of five percent as the minimal criterion of significance was used.

\section{Results}

\subsection{Effects of diethylnitrosoamine and Artemisia vulgaris on blood serum}

\subsubsection{Effect on ALAT}

Intraperitoneal administration of DEN (3.5 $\mu 1 / \mathrm{mg}$ body weight once in a week for eight consecutive weeks in mice) caused highly significant increase in levels of ALAT (control: $29.0 \pm 1.8 \mathrm{U} / \mathrm{L}$; DEN: $141.5 \pm 2.2 \mathrm{U} / \mathrm{L}$; AV: $37.3 \pm 2.0 \mathrm{U} / \mathrm{L})$. When extract of AV was given in combination with DEN no significant increase in levels of ALAT was observed (DEN+AV1: $73.2 \pm 2.3 \mathrm{U} / \mathrm{L})$. When extract of AV was injected intraperitoneally $(150 \mathrm{mg} / \mathrm{kg}$ body weight once in a week for eight consecutive weeks) in DEN treated mice, significant decrease in level of ALAT (DEN: $141.5 \pm 2.2 \mathrm{U} / \mathrm{L} ; \mathrm{DEN}+\mathrm{AV} 2: 127.5 \pm 2.5 \mathrm{U} / \mathrm{L}$ ) was observed (Figure 1).

\subsubsection{Effect on ASAT}

Intraperitoneal injection of DEN ( $3.5 \mu \mathrm{l} / \mathrm{mg}$ body weight once in a week for eight consecutive weeks in mice) showed tremendous increase in levels of ASAT (control: $87.9 \pm 2.7 \mathrm{U} / \mathrm{L} ; \mathrm{DEN}: 474.0 \pm 7.6 \mathrm{U} / \mathrm{L}: \mathrm{AV}: 113.6 \pm 5.1$ ). When extract of AV was given in combination with DEN 
no significant increase in levels of ASAT was observed $(\mathrm{DEN}+\mathrm{AV} 1: 214.6 \pm 3.1 \mathrm{U} / \mathrm{L})$. But, intraperitoneal administration of extract of AV (150 mg/ $\mathrm{kg}$ body weight once in a week for eight consecutive weeks) in DEN treated mice, resulted in significant decrease in level of ASAT (DEN: $474.0 \pm 7.6 \mathrm{U} / \mathrm{L} ; \mathrm{DEN}+\mathrm{LAV} 2: 443.3 \pm 7.7 \mathrm{U} / \mathrm{L}$ ) (Figure 1).
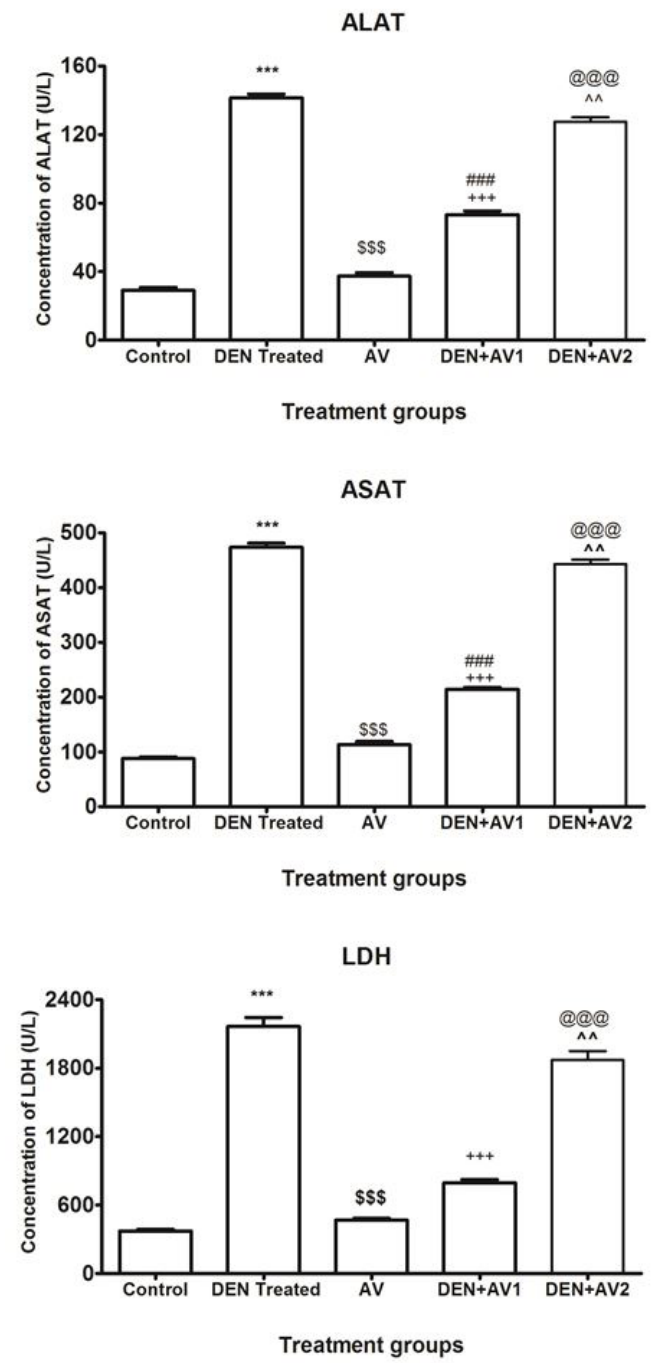

Figure 1. Analysis of Alanine Transaminase, Aspartate Transaminase and Lactate Dehydrogenase.

DEN, Diethylnitrosoamine; AV, extract of Artemisia vulgaris; $\mathbf{D E N}+\mathbf{A V} 1, \mathrm{DEN}$ and $\mathrm{AV}$ given at a time; DEN+AV2, treatment of DEN injected mice after eight weeks using AV *depicts differences between control and DEN treatment groups. "depicts differences between $\mathrm{BC} 2$ control and AV1 extract treatment groups. ${ }^{a}$ depicts differences between control and AV2 extract treatment

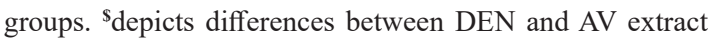
treatment groups. ${ }^{+}$depicts differences between DEN and AV1 extract treatment groups. ^ depicts differences between DEN and AV extract treatment groups. Each bar represents the mean value of seven replicates and SEM. Statistical icons: ${ }^{\wedge} \wedge=p \leq 0.01,{ }^{+++}$, @@@, ${ }^{\# \# \#, * * *, ~} \$ \$ \$=p \leq 0.001$.

\subsubsection{Effect on LDH}

DEN injected intraperitoneally $(3.5 \mu \mathrm{l} / \mathrm{mg}$ body weight once in a week for eight consecutive weeks in mice) resulted in highly significant increase in levels of LDH (control: $373.2 \pm 15.0 \mathrm{U} / \mathrm{L}$; DEN: $2165.7 \pm 78.9 \mathrm{U} / \mathrm{L}$; $\mathrm{AV}: 467.4 \pm 17.3 \mathrm{U} / \mathrm{L})$ When extract of $\mathrm{AV}$ was given in combination with DEN no significant increase in levels of LDH was observed (DEN + AV1: $797.0 \pm 27.2 \mathrm{U} / \mathrm{L})$. But, intraperitoneal administration of extract of AV $(150 \mathrm{mg} / \mathrm{kg}$ body weight once in a week for eight consecutive weeks) in DEN treated mice, resulted in significant decrease in level of $\mathrm{LDH}$ (DEN: $2165.7 \pm 78.9 \mathrm{U} / \mathrm{L} ; \mathrm{DEN}+\mathrm{AV} 2: 1871.8 \pm 76.9 \mathrm{U} / \mathrm{L})$ to significant value (Figure 1).

\subsubsection{Effect on AFP}

Highly significant increase in levels of Tumor marker AFP was caused by DEN $(3.5 \mu \mathrm{l} / \mathrm{mg}$ body weight in mice) once in a week for eight consecutive weeks (control: $13.5 \pm 0.9 \mathrm{ng} / \mathrm{ml}$; DEN: $63.4 \pm 2.4 \mathrm{ng} / \mathrm{ml}$; AV: $19.5 \pm 1.0 \mathrm{ng} / \mathrm{ml}$ ). When extract of AV was given in combination with DEN no significant increase in levels of AFP was observed (DEN + AV1: $41.5 \pm 2.7 \mathrm{ng} / \mathrm{ml})$. Significant decrease in level of AFP(DEN: $63.4 \pm 2.4 \mathrm{ng} / \mathrm{ml}$; $\mathrm{DEN}+\mathrm{AV} 2: 50.8 \pm 2.3 \mathrm{ng} / \mathrm{ml}$ ) was seen after intraperitoneal induction of extract of AV $(150 \mathrm{mg} / \mathrm{kg}$ body weight once in a week for eight consecutive weeks) in DEN treated mice (Figure 2)

\subsubsection{Effect on Bilirubin}

Level of bilirubin was also significantly increased (control: $0.9 \pm 0.1 \mathrm{mg} / \mathrm{dl}$; DEN: $2.9 \pm 0.2 \mathrm{mg} / \mathrm{dl} ; \mathrm{AV}: 1.1 \pm 0.1 \mathrm{mg} / \mathrm{dl}$ ) when DEN (3.5 $\mu \mathrm{l} / \mathrm{mg}$ body weight once in a week for eight consecutive weeks in mice) was injected intraperitoneally. When extract of AV was given in combination with DEN no significant increase in levels of bilirubin was observed $(\mathrm{DEN}+\mathrm{AV} 1: 1.3 \pm 0.2 \mathrm{U} / \mathrm{L})$. Intraperitoneal administration of extract of AV $(150 \mathrm{mg} / \mathrm{kg}$ body weight once in a week for eight consecutive weeks) in DEN treated mice, caused significant decrease in level of bilirubin (DEN: $2.9 \pm 0.2 \mathrm{mg} / \mathrm{dl}$; DEN+AV2: $1.9 \pm 0.1 \mathrm{mg} / \mathrm{dl}$ ) (Figure 2).

\subsubsection{Effect on Albumin}

Albumin level was significantly decreased (control: $6.2 \pm 0.4 \mathrm{U} / \mathrm{L}$; DEN: $2.8 \pm 0.2 \mathrm{U} / \mathrm{L} ; \mathrm{AV}: 5.7 \pm 0.3 \mathrm{U} / \mathrm{L})$ by intraperitoneal administration of DEN $(3.5 \mu \mathrm{l} / \mathrm{mg}$ body weight once in a week for eight consecutive weeks in mice). When extract of AV was given in combination with DEN no significant decrease in levels of albumin was observed (DEN + AV1: $4.2 \pm 0.2 \mathrm{U} / \mathrm{L})$. But intraperitoneal induction of extract of AV (150 mg/ $\mathrm{kg}$ body weight once in a week for eight consecutive weeks) in DEN treated mice, resulted in significant increase in level of albumin (DEN: $2.8 \pm 0.2 \mathrm{U} / \mathrm{L} ; \mathrm{AV} 2: 4.8 \pm 0.4 \mathrm{U} / \mathrm{L}$ ) (Figure 2).

\subsubsection{Effect on Y-GT}

Intraperitoneal injection of DEN (3.5 $\mu \mathrm{l} / \mathrm{mg}$ body weight once in a week for eight consecutive weeks in mice) caused highly significant increase in levels of Y-GT (control: $38.2 \pm 1.6 \mathrm{U} / \mathrm{L}$; DEN: $146.8 \pm 2.6 \mathrm{U} / \mathrm{L}$; 
$\mathrm{AV}: 49.7 \pm 3.2 \mathrm{U} / \mathrm{L})$. When extract of $\mathrm{AV}$ was given in combination with DEN no significant increase in levels of Y-GT was observed (DEN + AV1: $66.1 \pm 3.8 \mathrm{U} / \mathrm{L}$ ). But, intraperitoneal injection of extract of AV $(150 \mathrm{mg} / \mathrm{kg}$

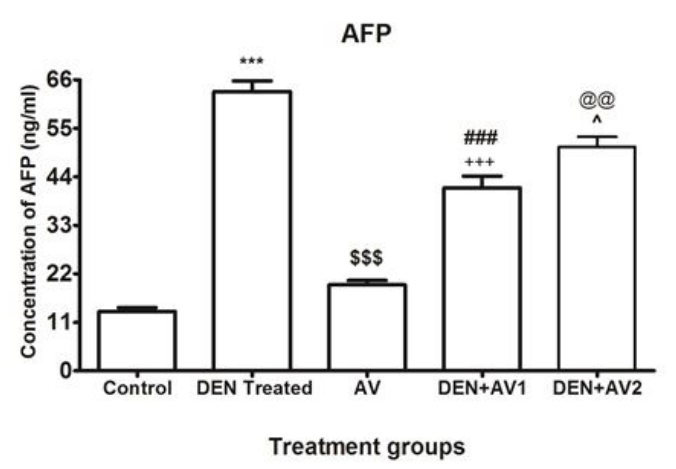

Bilirubin
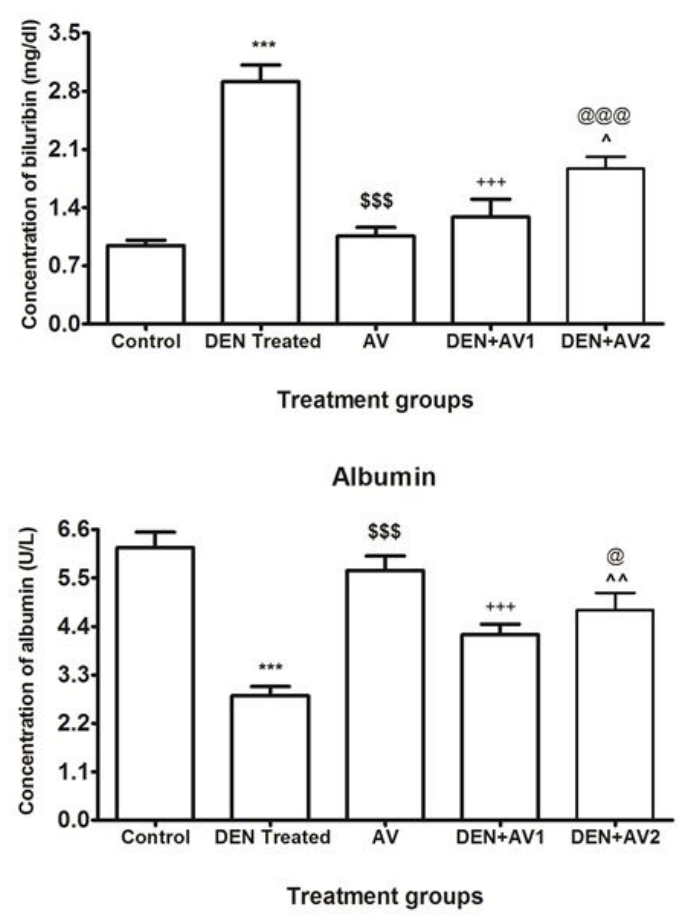

Figure 2. Analysis of Alpha Fetoprotein, Bilirubin and Albumin.

DEN, Diethylnitrosoamine; Av, extract of Artemisia vulgaris; DEN+AV1, DEN and AV given at a time; DEN+AV2, treatment of DEN injected mice after eight weeks using $\mathrm{AV}$ *depicts differences between control and DEN treatment groups. ${ }^{\# d e p i c t s ~ d i f f e r e n c e s ~ b e t w e e n ~ c o n t r o l ~}$ and AV1 extract treatment groups. ${ }^{a}$ depicts differences between control and AV2 extract treatment groups. ${ }^{\$}$ depicts differences between DEN and AV extract treatment groups. +depicts differences between DEN and AV1 extract treatment groups. ^ depicts differences between DEN and AV2 extract treatment groups. Each bar represents the mean value of seven replicates and SEM. Statistical icon: ${ }^{a} \wedge=p \leq 0.05$, @@, $\wedge \wedge=\mathrm{p} \leq 0.01,{ }^{+++},{ }^{\# \#, * * *, \$ \$ \$}=\mathrm{p} \leq 0.001$. body weight once in a week for eight consecutive weeks) in DEN treated mice, decreased the level of Y-GT (DEN: $146.8 \pm 2.6 \mathrm{U} / \mathrm{L}$; DEN + AV2: $131.2 \pm 3.2 \mathrm{U} / \mathrm{L}$ ) to a significant level (Figure 3 ).

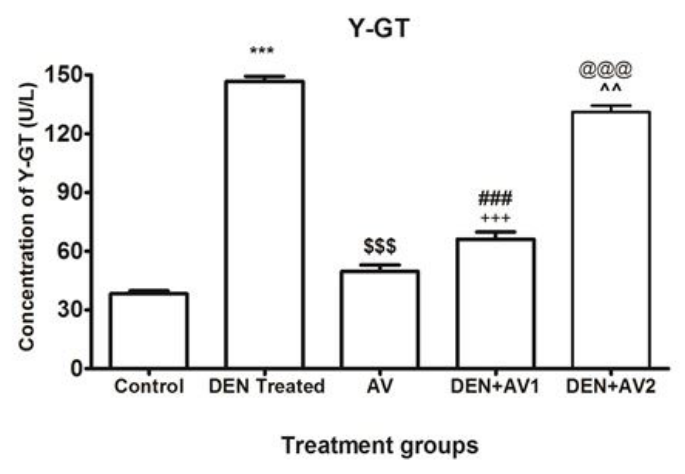

5 NT

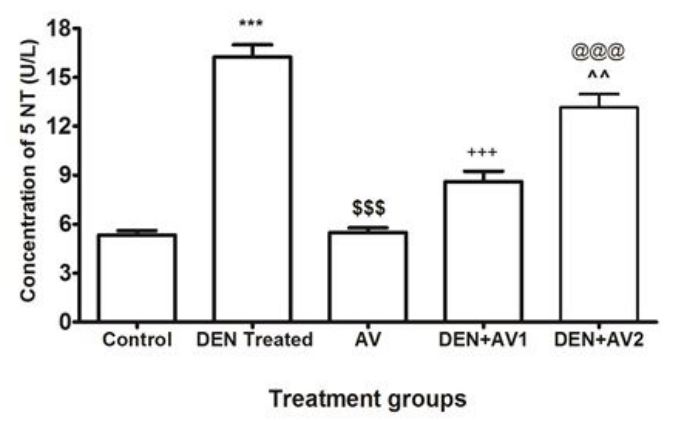

G6PDH

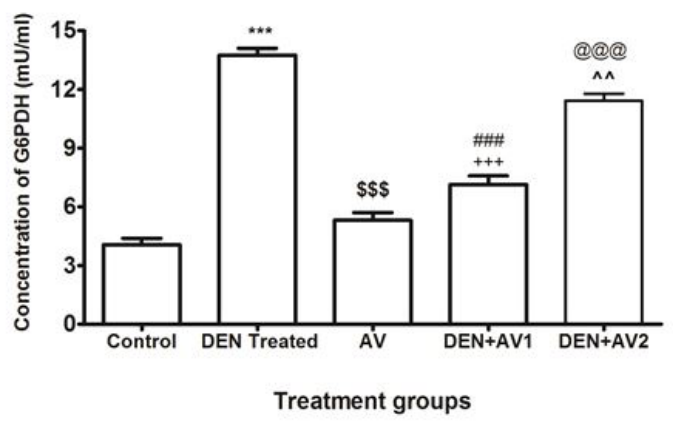

Figure 3. Analysis of Gamma Glutamyl Transferase, 5-Nucleotidase and Glucose 6 Phosphate Dehydrogenase.

DEN, Diethylnitrosoamine; AV, extract of Artemisia vulgaris; DEN+AV1, DEN and AV given at a time; DEN+AV2, treatment of DEN injected mice after eight weeks using AV *depicts differences between control and DEN treatment groups. "depicts differences between control and AV1 extract treatment groups. ${ }^{a}$ depicts differences between control and AV2 extract treatment

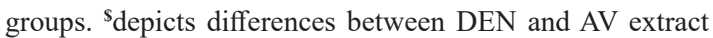
treatment groups. ${ }^{+}$depicts differences between DEN and AV1 extract treatment groups. ^ depicts differences between DEN and AV2 extract treatment groups. Each bar represents the mean value of seven replicates and SEM. Statistical icon: ${ }^{\wedge} \wedge=p \leq 0.01,{ }^{+++}$, @@@, ${ }^{\# \#, ~}, * * *, \$ \$ s=p \leq 0.001$. 


\subsubsection{Effect on $5 \mathrm{NT}$}

5 NT level was significantly increased (control: $5.3 \pm 0.3 \mathrm{U} / \mathrm{L}$; DEN: $16.3 \pm 0.7 \mathrm{U} / \mathrm{L} ; \mathrm{AV}: 5.5 \pm 0.3 \mathrm{U} / \mathrm{L})$ in mice by intraperitoneal induction of DEN $(3.5 \mu 1 / \mathrm{mg}$ body weight once in a week for eight consecutive weeks). When extract of AV was given in combination with DEN no significant increase in levels of $5 \mathrm{NT}$ was observed $(\mathrm{DEN}+\mathrm{AV} 1: 8.6 \pm 0.6 \mathrm{U} / \mathrm{L})$. But when extract of AV was administered intraperitoneally $(150 \mathrm{mg} / \mathrm{kg}$ once in a week for eight consecutive weeks) in DEN treated mice, significant decrease in levels of $5 \mathrm{NT}$ (DEN: $16.3 \pm 0.7 \mathrm{U} / \mathrm{L}$; $\mathrm{DEN}+\mathrm{AV} 2: 13.2 \pm 0.8 \mathrm{U} / \mathrm{L}$ ) was seen (Figure 3).

\subsubsection{Effect on G6PDH}

Intraperitoneal induction of DEN $(3.5 \mu 1 / \mathrm{mg}$ body weight once in a week for eight consecutive weeks in mice) caused highly significant increase in level of G6PDH (control: $4.1 \pm 0.3 \mathrm{mU} / \mathrm{ml}$; DEN: $13.7 \pm 0.4 \mathrm{mU} / \mathrm{ml}$; AV: $5.3 \pm 0.4 \mathrm{mU} / \mathrm{ml}$ ). When extract of $\mathrm{AV}$ was given in combination with DEN no significant decrease in levels of G6PDH was observed (DEN + AV1: $7.1 \pm 0.4 \mathrm{mU} / \mathrm{ml})$. G6PDH level was significantly decreased (DEN: $13.7 \pm 0.4 \mathrm{mU} / \mathrm{ml}$; $\mathrm{DEN}+\mathrm{AV} 2: 11.64 \pm 0.4 \mathrm{mU} / \mathrm{ml})$ when extract of AV was given intraperitoneally $(150 \mathrm{mg} / \mathrm{kg}$ body weight once in a week for eight consecutive weeks) in DEN treated mice (Figure 3).

\section{Discussion}

Diethylnitrosoamine is a commonly used chemical carcinogen for the liver because it is activated by cytochrome P-450 enzymes in hepatocytes (Kang et al., 2007). Elevated generation of ROS and diminished antioxidant enzymes in liver tissues has been reported in many models of DEN injected hepatic carcinogenesis (Sivaramakrishnan et al., 2008). In current research, we examined whether the extract of leaves of Artemisia vulgaris influence the toxicity and carcinogenesis of DEN in the Balb C mice. DEN (3.5 $\mu \mathrm{l} / \mathrm{mg})$ was administered in male Balb $\mathrm{C}$ mice at the age of four weeks. After eight weeks of DEN treatment, Balb C mice developed tumors.

Liver injury brought about by DEN generally demonstrates instability of hepatocyte metabolism that leads to distinct variations in the blood enzyme activities. Enzymes biomarkers are utilized for screening of specific malignancy conditions for prognosis, differential diagnosis, monitors the advances and for evaluating the reaction to treatment (Zimmer and Thomas, 2001). These enzymes are more specific and changes in their activities mirror the impact of multiplication of cells with development potential and its metabolic turnover. In the current research, elevation in pathophysiological marker protein levels upon DEN injection may be because of aggravation in the transport activities and the spillage of the enzymes.

Serum markers, Alpha-Fetoprotein (AFP), Gamma Glutamyl Transpeptidase ( $\gamma$-GT), 5'-Nucleotidase, Alanine Aminotransferase (ALAT) Aspartate Transaminase (AST), Lactate Dehydrogenase (LDH), Glucose 6-Phosphate
Dehydrogenase (G6PDH), albumin and total bilirubin are illustrative of liver function; increase in their level of ALT, AST, ALP, LDH and GGT but decrease in the level of albumin indicates liver damage and preneoplastic bruise (Gupta et al., 2010; Sadek et al., 2017). The study of Schmelzer et al. $(2006,2007)$ showed that A-fetoprotein is another recognized hepatocyte biomarker expressed differentially among hepatoblasts sand hepatic stem cell. A-fetoprotein (AFP) an oncofetal serum protein, is dynamically lost during development to such an extent that it is practically missing from the adults (Takayasu et al., 2006). It has for quite some time been perceived that presentation of rats to specific cancer-causing agents like DEN causes a rise of circulating AFP levels (Debruyne and Delanghe, 2008) Glutamyl Transpeptidase is an enzyme installed in the hepatocyte plasma membrane, for the most part in the canalicular space; again the leakage of this protein into serum demonstrates harm to the cell and liver damage. It is imperative to call attention to that serum $\gamma$-GT activity is thought to be one of the best pointers of liver injury (Bulle et al., 1990). In hepatocellular carcinoma, different biomarkers and enzymes are involved depends on the potential cellular toxicity of carcinogens or other elements playing part in causing and developing the disease. Alkaline phosphatase (ALP) a metalloenzyme is one of the factor catalyzing the phosphomonoesters (R-O-PO3), hydrolysis of phosphomonoesters, R-O-PO3, with little regard to the identity of the ' $\mathrm{R}$ ' group (Clifton and Titcomb, 2003). Increase in ALP level is an indicator for tumorgenesis (Al-Rejaie et al., 2009; Ibrahim and Nassar, 2008; Kew, 2012; Mohamed et al., 2012). Elevation of ALP in HCC group might be due to the disruption of secretory activity or alteration in gene expression (Sayed-Ahmed et al., 2010).

In this study, increase in serum Alpha-Fetoprotein (AFP), Gamma Glutamyl Transpeptidase ( $\gamma$-GT), 5'-Nucleotidase, Alanine Aminotransferase (ALAT) Aspartate Transaminase (ASAT), Lactate Dehydrogenase (LDH), Glucose 6-Phosphate Dehydrogenase (G6PDH), total bilirubin levels and decrease in levels of albumin upon infusion was related with increment in tumor development. After tumor induction extract of Artemisia vulgaris extract given to mice the decrease in tumor markers Alpha-Fetoprotein, Gamma Glutamyl Transpeptidase, 5'-Nucleotidase, Alanine Aminotransferase, Aspartate Transaminase, Lactate Dehydrogenase, Glucose 6-Phosphate Dehydrogenase, total bilirubin and increase in levels of albumin was found. After Artemisia vulgaris extract administration the levels of biological markers were decreased as compared to DEN treated value and almost equal values to control group showed reduction in the production rate of tumors, this showed that Artemisia vulgaris extract scavenged free radicals in the rat liver tissue.

\section{Conclusion}

This study showed that DEN induction resulted in a significant increase in Alpha-Fetoprotein, Gamma Glutamyl Transpeptidase, 5' -Nucleotidase, Alanine Aminotransferase, 
Aspartate Transaminase, Lactate Dehydrogenase, Glucose 6-Phosphate Dehydrogenase, total bilirubin levels and decrease in levels of albumin, indicated the induction of hepatocellular carcinoma. After the induction of hepatocellular carcinoma, the extract of Artemisia vulgaris caused decrease in values of Alpha-Fetoprotein, Gamma Glutamyl Transpeptidase, 5'-Nucleotidase, Alanine Aminotransferase, Aspartate Transaminase, Lactate Dehydrogenase, Glucose 6-Phosphate Dehydrogenase, total bilirubin levels and increase in levels of albumin and this decrease showed that extract of Artemisia vulgaris possess anti-cancerous activity against hepatocellular carcinoma and proven as a potential herb against tumor especially against hepatocellular carcinoma.

Compliance with Ethical Standards

Conflict of Interest: All authors declare there are no conflicts of interest.

Ethical approval: All applicable international, national, and/or institutional guidelines for the care and use of animals were followed. All animal trial techniques were directed as per local and worldwide controls. The nearby direction is the Wet op de dierproeven (Article 9) of Dutch Law (international) and a similar law regulated by the Bureau of Animal Experiment Licensing, local University.

Informed consent: This article does not contain any studies with human participants.

\section{Acknowledgements}

Authors are grateful to Azad Jammu and Kashmir University for providing funds for this study.

\section{References}

AGGARWAL, B.B. and SHISHODIA, S., 2006. Molecular targets of dietary agents for prevention and therapy of cancer. Biochemical Pharmacology, vol. 71, no. 10, pp. 1397-1421. http:// dx.doi.org/10.1016/j.bcp.2006.02.009. PMid:16563357.

AL-REJAIE, S.S.,ALEISA,A.M.,AL-YAHYA, A.A., BAKHEET, S.A., ALSHEIKH, A., FATANI, A.G., AL-SHABANAH, O.A., 2009. Progression of diethylnitrosamine induced hepatic carcinogenesis in carnitine, depleted rats. World Journal of Gastroenterology, vol. 21, no. 11, pp. 1373-1380. http://dx.doi.org/10.3748/wjg.15.1373. PMid:19294768.

BORA, K.S. and SHARMA, A., 2011. The Genus Artemisia: a comprehensive review. Pharmaceutical Biology, vol. 49, no. 1, pp. 101-109. http://dx.doi.org/10.3109/13880209.2010.497815 . PMid:20681755.

BULle, F., MAVIER, P., ZAFRANI, E.S., PREAUX, A.M., LESCS, M.C., SIEGRIST, S., DHUMEAUX, D. and GUELLAËN, G., 1990. Mechanism of $\gamma$-glutamyl transpeptidase release in serum during intrahepatic and extrahepatic cholestasis in the rat: A histochemical, biochemical and molecular approach. Hepatology, vol. 11, no. 4, pp. 545-550. http://dx.doi.org/10.1002/ hep.1840110404. PMid:1970323.

CLIFTON, P. and TITCOMB, J. 2003. Liver function tests: what is the risk. Journal of Insurance Medicine, vol. 35, no. 26, pp. 26-35.
DANGERFIELD, W.G. and FINLAYSON, R., 1953. Estimation of bilirubin in serum. Journal of Clinical Pathology, vol. 6, no. 3, pp. 173-177. http://dx.doi.org/10.1136/jcp.6.3.173. PMid:13084758.

DEBRUYNE, E.N. and DELANGHE, J.R., 2008. Diagnosing and monitoring hepatocellular carcinoma with alpha-fetoprotein: new aspects and applications. Clínica Chimica Acta, vol. 395, no. 1-2, pp. 19-26. http://dx.doi.org/10.1016/j.cca.2008.05.010. PMid: 18538135 .

FARAZI, P.A. and DEPINHO, R.A., 2006. Hepatocellular carcinoma pathogenesis: from genes to environment. Nature Reviews Cancer, vol. 6, no. 9, pp. 674-687. http://dx.doi.org/10.1038/nrc1934. PMid:16929323.

FEO, F., PASCALE, R.M., SIMILE, M.M., DE MIGLIO, M.R., MURONI, M.R. and CALVISI, D., 2000. Genetic alterations in liver carcinogenesis: implications for new preventive and therapeutic strategies. Critical Reviews in Oncogenesis, vol. 11, no. 1, pp. 19-62.

FERLAY, J., SHIN, H.R., BRAY, F., FORMAN, D., MATHERS, C. and PARKIN, D.M., 2010. Estimates of worldwide burden of cancer in 2008: GLOBOCAN 2008. International Journal of Cancer, vol. 127, no. 12, pp. 2893-2917. http://dx.doi.org/10.1002/ ijc.25516. PMid:21351269.

GEORGE, D.P. and ROGER, M.D., 2000. Encyclopedia of medicinal plants: education and health library. Madrid: Editorial Safeliz, vol. 2, 624 p.

GUPTA, C., VIKRAM, A., TRIPATHI, D.N., RAMARAO, P. and JENA, G.B., 2010. Antioxidant and antimutagenic effect of quercetin against DEN induced hepatotoxicity in rat. Phytotherapy Research, vol. 24, no. 1, pp. 119-128. http://dx.doi.org/10.1002/ ptr.2883. PMid:19504466.

HAFEEZ, K., ANDLEEB, S., GHOUSA, T.G., MUSTAFA, R., NASEER, A., SHAFIQUE, I. and AKHTER, K., 2017. Phytochemical screening, alpha-glucosidase inhibition, antibacterial and antioxidant potential of Ajuga bracteosa extracts. Current Pharmaceutical Biotechnology, vol. 18, no. 4, pp. 336-342. http:// dx.doi.org/10.2174/1389201018666170313095033. PMid:28294059.

HUSSAIN, T., SIDDIQUI, H.H., FAREED, S., VIJAYAKUMAR, M. and RAO, C.V., 2012. Evaluation of chemopreventive effect of Fumaria indica against $\mathrm{N}$-nitrosodiethylamine and $\mathrm{CCl}$ 4-induced hepatocellular carcinoma in Wistar rats. Asian Pacific Journal of Tropical Medicine, vol. 5, no. 8, pp. 623-629. http://dx.doi. org/10.1016/S1995-7645(12)60128-X. PMid:22840450.

IBRAHIM, S.S. and NASSAR, N.N., 2008. Diallylsulfide protects against N-nitrosodiethylamineinduced liver tumorigenesis: role of aldose reductase. World Journal of Gastroenterology, vol. 14, no. 40, pp. 6145-6153. http://dx.doi.org/10.3748/wjg.14.6145. PMid: 18985804.

JEMAL, A., BRAY, F., CENTER, M.M., FERLAY, J., WARD, E. and FORMAN, D., 2011. Global cancer statistics. CA: A Cancer Journal for Clinicians, vol. 61, no. 2, pp. 69-90. http://dx.doi. org/10.3322/caac.20107. PMid:21296855.

KANG, J.S., WANIBUCHI, H., MORIMURA, K., GONZALEZ, F.J. and FUKUSHIMA, S., 2007. Role of CYP2E1 in diethylnitrosamineinduced hepatocarcinogenesisin vivo. Cancer Research, vol. 67, no. 23, pp. 11141-11146. http://dx.doi.org/10.1158/0008-5472. CAN-07-1369. PMid:18056438.

KAPOOR, L.D., 2000. CRC Handbook of Ayurvedic medicinal plants. Boca Raton: CRC Press, $53 \mathrm{p}$.

KEW, C.M., 2012. Hepatocellular carcinoma in developing countries: Prevention, diagnosis and treatment. World Journal of Hepatology, vol. 4, no. 3, pp. 99-104. http://dx.doi.org/10.4254/ wjh.v4.i3.99. PMid:22489262. 
KHAN, M.S., HALAGOWDER, D. and DEVARAJ, S.N., 2011. Methylated chrysin, a dimethoxy flavone, partially suppresses the development of liver preneoplastic lesions induced by N-Nitrosodiethylamine in rats. Food and Chemical Toxicology, vol. 49, no. 1, pp. 173-178. http://dx.doi.org/10.1016/j.fct.2010.10.013. PMid:20955752.

KING, J., 1965. The dehydrogenases or oxidoreductases: lactate dehydrogenase. In: D. VAN, ed. Practical clinical enzymology. London: Van Nostrand, pp. 83-93.

LI, Y., 2012. Qinghaosu (artemisinin): chemistry and pharmacology. Acta Pharmacologica Sinica, vol. 33, no. 9, pp. 1141-1146. http:// dx.doi.org/10.1038/aps.2012.104. PMid:22922345.

MACNAB, G.M., URBANOWICZ, J.M. and KEW, M.C., 1978. Carcinoembryonic antigen in hepatocellular cancer. British Journal of Cancer, vol. 38, no. 1, pp. 51-54. http://dx.doi.org/10.1038/ bjc.1978.162. PMid:80223.

MCINTYRE, N. and ROSALKI, S., 1992. Biochemical investigations in the management of liver disease. In J. PRIETO, J. RODÉS and D.A. SHAFRITZ. Hepatobiliary diseases. Heidelberg: Springer, pp. 39-71. http://dx.doi.org/10.1007/978-3-642-76802-6_2.

MINUCCI, A., GIARDINA, B., ZUPPI, C. and CAPOLUONGO, E., 2009. Glucose-6-phosphate dehydrogenase laboratory assay: How, when, and why? IUBMB Life, vol. 61, no. 1, pp. 27-34. http:// dx.doi.org/10.1002/iub.137. PMid:18942156.

MOHAMED, N., MAIDEEN, P., VELAYUTHAM, R. and MANAVALAN, G., 2012. Activity of Prosopis cineraria against Nnitrosodiethylamine induced liver tumors by regulating the levels of Tumor marker, Lipid peroxidation and Antioxidants. Asian Journal of Pharmacy and Life Science., vol. 2, no. 1, pp. 2231-4423.

NEWTON, P., SUPUTTAMONGKOL, Y., TEJA-ISAVADHARM, P., PUKRITTAYAKAMEE, S., NAVARATNAM, V., BATES, I. and WHITE, N., 2000. Antimalarial bioavailability and disposition of artesunate in acute falciparum malaria. Antimicrobial Agents and Chemotherapy, vol. 44, no. 4, pp. 972-977. http://dx.doi.org/10.1128/ AAC.44.4.972-977.2000. PMid:10722499.

RAMAKRISHNAN, G., RAGHAVENDRAN, H.R.B., VINODHKUMAR, R. and DEVAKI, T., 2006. Suppression of $\mathrm{N}$-nitrosodiethylamine induced hepatocarcinogenesis by silymarin in rats. Chemico-Biological Interactions, vol. 161, no. 2, pp. 104114. http://dx.doi.org/10.1016/j.cbi.2006.03.007. PMid:16643877.

RAVINDRANATH, M.H., RAMASAMY, V., MOON, S., RUIZ, C. and MUTHUGOUNDER, S., 2009. Differential growth suppression of human melanoma cells by tea (Camellia sinensis) epicatechins (ECG, EGC and EGCG). Evidence-Based Complementary and Alternative Medicine, vol. 6, no. 4, pp. 523530. http://dx.doi.org/10.1093/ecam/nem140. PMid:18955299.

REITMAN, S. and FRANKEL, S., 1957. A colorimetric method for the determination of serum glutamic oxalacetic and glutamic pyruvic transaminases. American Journal of Clinical Pathology, vol. 28, no. 1, pp. 56-63. http://dx.doi.org/10.1093/ajcp/28.1.56. PMid: 13458125

RIEDER, S.V. and OTERO, M., 1969. A simplified procedure for the Assay of 5'-Nucleotidase. Clinical Chemistry, vol. 15, no. 8, pp. 727-729. PMid:4309139.

SADEK, K.M., ABOUZED, T.K., ABOUELKHAIR, R. and NASR, S., 2017. The chemo-prophylactic efficacy of an ethanol Moringaoleifera leaf extract against hepatocellular carcinoma in rats. Pharmaceutical Biology, vol. 55, no. 1, pp. 1458-1466. http:// dx.doi.org/10.1080/13880209.2017.1306713. PMid:28345375.

SAVORY, J., HEINTGES, M.G., SONOWANE, M. and CROSS, R.E., 1976. Measurement of total protein and albumin in serum with a centrifugal analyzer. Clinical Chemistry, vol. 22, no. 7, pp. 1102-1104. PMid:1277510.

SAYED-AHMED, M.M., ALEISA, M.A., AL-REJAIE, S.S., AL-YAHYA, A., AL-SHABANAH, A.O., HAFEZ, M.M. and NAGI, N.M., 2010. Thymoquinone attenuates diethylnitrosamine induction of hepatic carcinogenesis through antioxidant signaling. Oxidative medicine and cellular longevity, vol. 3, no. 4, pp. 254261. PMid:20972371.

SCHMELZER, E., WAUTHIER, E. and REID, L.M., 2006. The phenotypes of pluripotent human hepatic progenitors. Stem Cells, vol. 24, no. 8, pp. 1852-1858. http://dx.doi.org/10.1634/ stemcells.2006-0036. PMid:16627685.

SCHMELZER, E., ZHANG, L., BRUCE, A., WAUTHIER, E., LUDLOW, J., YAO, H.L., MOSS, N., MELHEM, A., MCCLELLAND, R., TURNER, W., KULIK, M., SHERWOOD, S., TALLHEDEN, T., CHENG, N., FURTH, M.E. and REID, L.M., 2007. Human hepatic stem cells from fetal and postnatal donors. The Journal of Experimental Medicine, vol. 204, no. 8, pp. 19731987. http://dx.doi.org/10.1084/jem.20061603. PMid:17664288.

SELL, S. and BECKAR, F., 1978. Alpha-Fetoprotein. Journal of the National Cancer Institute, vol. 60, no. 1, pp. 19-26.

SELL, S., BECKER, F., LEFFERT, H., OSBORN, K., SALMAN, J., LOMBARDI, B., SHINOZUKA, H., REDDY, J., RUOSLAHTI, E. and SALA-TREPAT, J., 1983. Alphafetoprotein as a marker for early events and carcinoma development during chemical hepatocarcinogenesis. In: H.A. MILMAN and S. SELL. Application of biological markers to carcinogen testing. New York: Springer, pp. 20-40. http://dx.doi.org/10.1007/978-1-4613-3790-4_22.

SHAIK, I. and HUSSAIN, S.J., 2004. Some important herbs used in the treatment of cancer: part I. Role of biotechnology in medicinal and aromatic plants. Hyderabad: Ukaaz Publications, vol. 11 , pp. 10-11.

SINGH, B.N., SINGH, B.R., SARMA, B.K. and SINGH, H.B., 2009. Potential chemoprevention of N-nitrosodiethylamine-induced hepatocarcinogenesis by polyphenolics from Acacia nilotica bark. Chemico-Biological Interactions, vol. 181, no. 1, pp. 20-28. http:// dx.doi.org/10.1016/j.cbi.2009.05.007. PMid:19446540.

SIVARAMAKRISHNAN, V., SHILPA, P.N., PRAVEEN KUMAR, V.R. and NIRANJALI DEVARAJ, S., 2008. Attenuation of N-nitrosodiethylamine-induced hepatocellular carcinogenesis by a novel flavonol: morin. Chemico-Biological Interactions, vol. 171, no. 1, pp. 79-88. http://dx.doi.org/10.1016/j.cbi.2007.09.003. PMid:17950263.

SZASZ, G., 1976. Reaction-rate method for gamma-glutamyltransferase activity in serum. Clinical Chemistry, vol. 22, no. 12, pp. 20512055. PMid:11903.

TAKAYASU, K., ARII, S., IKAI, I., OMATA, M., OKITA, K., ICHIDA, T. and YAMAOKA, Y., 2006. Prospective cohort study of transarterial chemoembolization for unresectable hepatocellular carcinoma in 8510 patients. Gastroenterology, vol. 131, no. 2, pp. 461-469. http://dx.doi.org/10.1053/j.gastro.2006.05.021. PMid: 16890600

TEPPERMAN, H.M. and TEPPERMAN, J., 1962. Role of hormones in glucose-6-phosphate dehydrogenase adaptation of rat liver. American Journal of Physiology-Legacy Content, vol. 202, no. 3, pp. 401-406

WALTER, H.L. and MEMORY, P.F., 2003. Medical botany: plants affecting human health. 2nd ed. New Jersey: Wiley, 345 p.

ZIMMER, R. and THOMAS, P., 2001. Mutations in the carcinoembryonic antigen gene in colorectal cancer patients. Cancer Research, vol. 61, no. 7, pp. 2822-2826. PMid:11306451. 